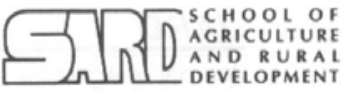

কৃষि ও পল्षী উन्नয়न অनूयদ
Available online at

http:/ / www.banglajol.info/index.php/jard
J ARD

Journal of Agriculture

\& Rural Development

\title{
Nutritional Status of the Members of the Factory Worker-Headed Households of Four Villages of Gazipur District
}

\author{
S. S. DIPTI ${ }^{1}$, M. A. G. TUAZON ${ }^{2} \&$ K. A. KABIR ${ }^{* 3}$ \\ ${ }^{1 \& 3}$ Grain Quality and Nutrition Division, Bangladesh Rice Research Institute, Gazipur, Bangladesh \\ ${ }^{2}$ Institute of Human Nutrition and Food, College of Human Ecology, University of the Philippines, \\ Los Baños, College, Laguna, Philippines 4031
}

\begin{abstract}
The study was undertaken to determine the nutritional status of factory worker-headed households in four semi-urban villages (i.e. Board Bazar, Signboard, Bhogra and Zogitola under Gazipur district) during June 2005. Data were collected from 100 randomly selected factory workers who are head of the households in the study area covering a total of 457 people and their 86 pre-school children. Prevalence rates of malnutrition were determined by using weight-for-age, height-for-age and weightfor-height classification. A total of $73.3 \%$ pre-school children were underweight, $72.1 \%$ had stunted growth and $27.9 \%$ were wasted. Prevalence of underweight for age was also found in $71.5 \%$ of school children. Body mass index (BMI) was used to assess either under-nutrition (chronic energy malnutrition) or over-nutrition in adults (20 years and over). Prevalence of chronic energy malnutrition among adult members was found $57.7 \%$ for male and $56.5 \%$ for female.
\end{abstract}

Key words: Weight-for-age, height-for-age, weight-for-height, Body Mass Index (BMI).

\section{INTRODUCTION}

Malnutrition is a widespread public health problem in developing countries. According to FAO, 2002, 799 million people in the developing world were chronically undernourished in 1998-2000. Even more people are debilitated by deficiencies associated with poor nutrition, especially of vitamin A, iron and iodine (ACC/SCN, 2000). It adversely affects an individual's physical and mental development, productivity and the span of productive years. Thus, significantly influencing the social behavior and economic potential of man. This problem is most prevalent among the vulnerable sectors of the population particularly those residing in socio-economically depressed urban and rural areas. Within these groups, infants and children are predominantly affected. If malnutrition in childhood continues to exist and increase, the development of the nation's human resource potential is adversely affected which, therefore, has serious implications in many areas. It may continue to be a major impediment to national development if not corrected.

The pervasive poverty and the constraints of ensuring food and nutrition security for the population in Bangladesh is reflected in the health statistics. The child mortality rates in Bangladesh are 79 per 1000 live births and 106 per 1000 children do not reach five years of age (UNICEF, 1999). It has been estimated that $50-60 \%$ of all less than five death are attributed directly or indirectly to malnutrition (GPRB, 1995). Child Nutrition Survey of Bangladesh revealed that, $51 \%$ of

* Corresponding author: Chief Scientific Officer \& Head, GQ\&N Division, BRRI, Gazipur-1701; Tel. 01715006899; E-mail: kabirka@gmail.com

(C) 2008 School of Agriculture and Rural Development, Bangladesh Open University, All rights reserved. 
children between 6 to 71 months of age suffered from chronic malnutrition (low height-for-age) whereas $8 \%$ suffered from acute malnutrition (low weight-for-height) (BBS, 1997).

Distribution of foods in the household depends on cultural habits, education, decision-making and recognition of the nutritional needs of each household member (Chen et al., 1981; Kramer et al., 1997). In the child nutrition survey of 1995-1996 in Bangladesh, it was found that maternal literacy rate was indeed positively correlated with height-for-age and weight-for-height in children (BBS, 1997). The presence or absence of infections can reduce appetite and/or nutrient absorption (Jalal, et al., 1998; Fairbanks, 1994; Olsen, 1994).

Malnutrition is not only a problem among the pre-school children but also among households specifically those whose heads belong to the occupational groups that are nutritionally disadvantaged like the factory workers. Dietary intakes of farm workers households were shown to be deficient in essential nutrients (Villavieja, 1984), 34.6\% of these households were below the food thresholds implying the pervasiveness of poverty in this occupational group. It reduces future adult labor productivity due to young child malnutrition, but this large part of population is giving an excellent support to the countries economy.

The occupational group of factory workers, therefore, deserves special attention because they are one of the backbones of the industrial sector. This group likewise has important needs that must be fulfilled in the midst of declining standards of living.

Children below the age of 5 years constitute a major vulnerable segment of the population from the nutritional standpoint. Over half of the deaths of this age group could be considered malnutrition related. FAO (1970) contend that malnutrition is the biggest single contributor to child mortality in the developing countries. Further, those malnourished children who survive may be physically and mentally debilitated, perhaps irreparably. A great majority of young children who belong to the poor income group in the developing countries are malnourished. They suffer from various grades of protein energy malnutrition ranging from mild degrees of growth retardation to the very severe forms of kwashiorkor or marasmus. Malnourished children are more susceptible to infection (Puffer, et al., 1973). For pre-school children in the less privileged groups of developing countries, whether the apparent clinical result is nutritional or infectious disease, both malnutrition and infection are usually involved. It is the interaction of inadequate dietary intake and repeated infections that is responsible for the severe impairment of growth and development during the pre-school years among the lower income population of nearly all developing countries (Scrimshaw et al., 1968). It is now recognized that extraordinarily high frequency of infection prevails among the pre-school children of lower income groups of the developing countries. In several studies socio-economic factors have been found to influence the nutritional status of the children. De Lira et al. (1985) observed that, children with landless families suffered from high rate of malnutrition than children's with landowners. A significant correlation has been found between protein energy malnutrition (PEM) and the size of land. Brown et al. (1986) found that, children in the low-income area of south East Asia are at highest nutritional risk.

In these circumstances the study was conducted to know the nutritional status of the members of the factory worker headed household. The study was supposed to give us a new understanding as to how future nutritional interventions can address the problems affecting the factory workers living in semi-urban areas.

\section{MATERIALS AND METHODS}

The study was conducted in four semi-urban villages of Gazipur district in Bangladesh. The study was conducted over 100 households in the study area covered by Board Bazar, Signboard, Bhogra and Zogitola representing the household population. Random selection was done based on the presence of nutritionally-at-risk occupational groups of the factory workers.

\section{Nutritional status assessment}

Nutritional status of all the children belonging to the household samples was analyzed by comparing their actual height and weight data with the National Center for Health Statistics (NCHS) standards using $\mathrm{Z}$ score. To measure the nutritional status of adults, Body Mass Index (BMI) was used. BMI 
provides a measure of body mass, ranging from thinness to obesity. Four indices were used in this study to assess the nutritional status of members of factory worker-headed households. These were weight-for-age, height-for-age and weight-for-height for children. On the other hand, BMI was used to assess either under-nutrition (chronic energy malnutrition) or over-nutrition in adults.

\section{RESULTS AND DISCUSSION}

\section{Pre-school children (0-6 years old)}

\section{Prevalence of underweight}

On average $74.1 \%$ of preschool children were underweight for their age (Table 1). This indicates that prevalence of underweight was high among pre-school children of factory worker-headed households and only $25.9 \%$ were normal for their age. All $(100 \%)$ underweight-for-age was observed among the two year old members. Breast feeding pattern of children were not included in the data collection. The poor weaning practices at this critical age of two year could have contributed to the high prevalence of underweight.

Table 1. Percentage distribution of 0-6 years old children by weight-for-age classification using NCHS standards

\begin{tabular}{cccc}
\hline Age & Total Subject & \multicolumn{2}{c}{$\%$ Distribution by weight-for-age } \\
\cline { 3 - 4 } (in years) & & Underweight $(<-2 \mathrm{SD})$ & Normal $(-2$ SD to $<+2$ SD) \\
\hline$<1$ year & 11 & 54.5 & 45.5 \\
1 & 8 & 75.0 & 25.0 \\
2 & 8 & 100.0 & 0.0 \\
3 & 15 & 73.3 & 26.7 \\
4 & 13 & 76.9 & 23.1 \\
5 & 13 & 61.5 & 38.5 \\
6 & 18 & 77.8 & 22.2 \\
\hline Total & 86 & 74.1 & 25.9 \\
\hline
\end{tabular}

\section{Prevalence of under height-for-age (stunting)}

Average $72.2 \%$ of pre-school children were found to be stunted for their age (Table 2). The highest proportion of stunting was observed among the $<1$ year old, followed by the 2 years old. This was due to the carry over effect of malnutrition in early years of these children which is now manifesting in their physical growth.

Table 2. Percentage distribution of 0-6 years old children by height-for-age classification using NCHS standards

\begin{tabular}{cccc}
\hline $\begin{array}{c}\text { Age } \\
\text { (in years) }\end{array}$ & $\begin{array}{c}\text { Total } \\
\text { Subject }\end{array}$ & Stunted (<-2SD) & Normal (-2SD to <+2SD) \\
\cline { 3 - 4 }$<1$ year & 11 & 90.9 & 9.1 \\
1 & 8 & 75.0 & 25.0 \\
2 & 8 & 87.5 & 12.5 \\
3 & 15 & 73.3 & 26.7 \\
4 & 13 & 76.9 & 23.1 \\
5 & 13 & 46.2 & 53.8 \\
6 & 18 & 55.6 & 44.4 \\
\hline Total & 86 & 72.2 & 27.8 \\
\hline
\end{tabular}

\section{Prevalence of underweight-for-height (wasting)}

Wasting was mostly found among the three year old children followed by 4 years (Table 3 ). Of the underweight-for-height children, on an average $25.8 \%$ were wasted while $2.6 \%$ of overweight. Two-thirds $(71.6 \%)$ of the children however, were classified as having normal weight-for-height. Thus malnutrition appeared to be rampant among pre-school children of the nutritionally-at-risk group of factory workers. This might be due to poor diet quality for the member of the factory worker headed households. 
S. S. Dipti et al.

Table 3. Percentage distribution of 0-6 years old children by weight-for-height classification using NCHS standards

\begin{tabular}{|c|c|c|c|c|}
\hline \multirow{2}{*}{$\begin{array}{c}\text { Age } \\
\text { (in years) }\end{array}$} & \multirow{2}{*}{$\begin{array}{c}\text { Total } \\
\text { Subject }\end{array}$} & \multicolumn{3}{|c|}{$\%$ Distribution by weight-for-height } \\
\hline & & Wasted (<-2SD) & Normal (-2SD to <+2SD) & Overweight $(\geq+2 S D)$ \\
\hline$<1$ year & 11 & 9.1 & 72.7 & 18.2 \\
\hline 1 & 8 & 12.5 & 87.5 & 0.0 \\
\hline 2 & 8 & 25.0 & 75.0 & 0.0 \\
\hline 3 & 15 & 46.7 & 53.3 & 0.0 \\
\hline 4 & 13 & 38.5 & 61.5 & 0.0 \\
\hline 5 & 13 & 15.4 & 84.6 & 0.0 \\
\hline 6 & 18 & 33.3 & 66.7 & 0.0 \\
\hline Total & 86 & 25.8 & 71.6 & 2.6 \\
\hline
\end{tabular}

From the point of view of the both the height and weight-for-age (stunting and underweight), $73.4 \%$ of children were found to be malnourished in Bangladesh in 1995-1996 (Jahan and Hossain, 1998). This means that only a little more than a quarter of the children can be regarded as normal as far as their physical growth is concerned. Estimated from the points of view of height-for-age and weight-for-height (stunting and wasting), however, a some what different picture can be found on malnourishment. Prevalence of weight-for-age or underweight is very high, that of weight-forheight or wasting is not that high. This means that the great majority of children do not have adequate access to food and nutrients. This impedes their expected weight gain. Only a few suffer due to acute food shortage and illness and become wasted (Jahan and Hossain, 1998).

\section{School Children (7-10 years old)}

\section{Prevalence of underweight}

Of the 57 school children belonging to the $7-10$ years of age category, $71.5 \%$ were underweight for their age (Table 4). The greatest proportion of underweight-for-age was observed among the 7 and 8 years old children.

Table 4. Percentage distribution of 7-10 years old children by weight-for-age classification using NCHS standards

\begin{tabular}{cccc}
\hline Age & Total & \multicolumn{2}{c}{$\%$ Distribution by weight-for-age } \\
\cline { 2 - 4 } (in years) & Subject & Underweight (<-2SD) & Normal (-2SD to <+2SD) \\
\hline 7 & 16 & 87.5 & 12.5 \\
8 & 13 & 76.9 & 23.1 \\
9 & 14 & 57.1 & 42.9 \\
10 & 14 & 64.3 & 35.7 \\
\hline Total & 57 & 71.5 & 28.5 \\
\hline
\end{tabular}

\section{Prevalence of under height-for-age}

Among 7 to 10 years old children, $59.4 \%$ were found to be stunted. The highest proportion of stunting was observed among the seven years old school children $(68.8 \%)$ followed by the eight $(61.5 \%)$ and nine $(64.3 \%)$ years old children.

Table 5. Percentage distribution of 7-10 years old children by height-for-age classification using NCHS standards

\begin{tabular}{cccc}
\hline Age & Total & \% Distribution by height-for-age \\
\cline { 2 - 4 } (in years) & Subject & Stunted (<-2SD) & Normal (-2SD to <+2SD) \\
\hline 7 & 16 & 68.8 & 31.2 \\
8 & 13 & 61.5 & 38.5 \\
9 & 14 & 64.3 & 35.7 \\
10 & 14 & 42.9 & 57.1 \\
\hline Total & 57 & 59.4 & 40.6 \\
\hline
\end{tabular}




\section{Adolescents (11 to 19 years old)}

Table 6 shows the distribution of nutritional status of adolescents. In both cases of male and female adolescents $17.1 \%$ have normal BMI levels. The prevalence of chronic energy deficiency (CED) among male adolescents (BMI of $<18.5$ ) is $53.6 \%$. The prevalence is higher in males than in females $(45.7 \%)$. No overweight adolescent male and female was found in factory worker households.

Table 6. Percentage distribution of adolescents (11-19 years old) using BMI by age and sex

\begin{tabular}{|c|c|c|c|c|c|c|c|}
\hline $\begin{array}{l}\text { Age Group } \\
\text { (years)/sex }\end{array}$ & Total Subject & $\begin{array}{c}3^{\text {rd }} \text { CED } \\
<16\end{array}$ & $\begin{array}{c}2^{\text {nd }} \text { CED } \\
16.0-<17.0\end{array}$ & $\begin{array}{c}1^{\text {st }} \text { CED } \\
17.0-<18.5\end{array}$ & $\begin{array}{l}\text { Total } \\
\text { CED }\end{array}$ & $\begin{array}{c}\text { Low Normal } \\
18.5-<20.0\end{array}$ & $\begin{array}{c}\text { Normal } \\
20.0-<25.0\end{array}$ \\
\hline \multicolumn{8}{|l|}{ Male } \\
\hline $11-12$ & 13 & 15.4 & 23.1 & 38.4 & 76.9 & 23.1 & \\
\hline $13-19$ & 28 & 3.6 & 17.9 & 21.4 & 42.9 & 32.1 & 25.0 \\
\hline Total & 41 & 7.3 & 19.5 & 26.8 & 53.6 & 29.3 & 17.1 \\
\hline \multicolumn{8}{|l|}{ Female } \\
\hline $11-12$ & 8 & 12.5 & 12.5 & 12.5 & 37.5 & 62.5 & \\
\hline $13-19$ & 27 & 18.5 & 7.4 & 22.2 & 48.1 & 29.6 & 22.2 \\
\hline Total & 35 & 17.1 & 8.6 & 20.0 & 45.7 & 37.1 & 17.1 \\
\hline
\end{tabular}

\section{Adults (20 years and above)}

Table 7 shows the percent distribution of nutritional status of adults (20 years and above) males and females according to their BMI. Highest percentage of male adults $(57.7 \%)$ and female adults $(56.5 \%)$ were suffering from chronic energy malnutrition. Male $(17.9 \%)$ and female $(19.1 \%)$ have normal BMI. Prevalence of obesity was found among male adult (1.6\%). The high proportion of adults with low BMI indicates food inadequacy and/or widespread infection and parasitic infestations which lead to poor absorption and utilization of food (Jahan and Hossain, 1998).

Table 7. Percentage distribution of adults (20 years and above) using BMI by age and sex

\begin{tabular}{|c|c|c|c|c|c|c|c|c|}
\hline $\begin{array}{l}\text { Age Group } \\
\text { (years)/sex }\end{array}$ & $\begin{array}{c}\text { Total } \\
\text { Subject }\end{array}$ & $\begin{array}{c}3^{\text {rd }} \text { CED } \\
<16\end{array}$ & $\begin{array}{c}2^{\text {nd }} \text { CED } \\
16.0-<17.0\end{array}$ & $\begin{array}{c}1^{\text {st }} \text { CED } \\
17.0-<18.5\end{array}$ & $\begin{array}{l}\text { Total } \\
\text { Ced } \\
\end{array}$ & $\begin{array}{c}\text { Low Normal } \\
18.5-<20.0 \\
\end{array}$ & $\begin{array}{c}\text { Normal } \\
20.0-<25.0\end{array}$ & $\begin{array}{l}1^{\text {st }} \text { OBESE } \\
25.0-<30.0 \\
\end{array}$ \\
\hline \multicolumn{9}{|l|}{ Male } \\
\hline $20-39$ & 70 & 2.9 & 10.0 & 44.3 & 57.2 & 25.7 & 14.3 & 2.9 \\
\hline $40-59$ & 36 & 13.9 & 5.6 & 33.3 & 52.8 & 22.2 & 25.0 & 0.0 \\
\hline $60 \&$ above & 17 & 11.8 & 29.4 & 29.4 & 70.6 & 11.8 & 17.6 & 0.0 \\
\hline Total & 123 & 7.3 & 11.4 & 39.0 & 57.7 & 22.8 & 17.9 & 1.6 \\
\hline \multicolumn{9}{|l|}{ Female } \\
\hline $20-39$ & 75 & 9.3 & 12.0 & 33.3 & 54.6 & 24.0 & 21.3 & 0.0 \\
\hline $40-59$ & 22 & 22.7 & 13.6 & 18.2 & 54.5 & 31.8 & 13.6 & 0.0 \\
\hline $60 \&$ above & 18 & 16.7 & 38.9 & 11.1 & 66.7 & 16.7 & 16.7 & 0.0 \\
\hline Total & 115 & 13.0 & 16.5 & 27.0 & 56.5 & 24.3 & 19.1 & 0.0 \\
\hline
\end{tabular}

\section{CONCLUSION}

Findings from this study revealed that a high prevalence of malnutrition exists among the members of the factory worker-headed households. The majority of adolescents in factory worker-headed households were found to be suffering from physical retardation. The BMI data shows that the adolescent females are less affected by thinness than males.

\section{LITERATURE CITED}

ACC/SCN. 2000. Forth report on the world nutrition situation: Nutrition throughout the life cycle. Administrative Committee on Coordination Sub-Committee on nutrition in collaboration with the International Food Policy Research Institute, Geneva. 
Bangladesh Bureau of Statistics (BBS). 1997. "Child Nutrition Survey of Bangladesh 1995-1996". Bangladesh Bureau of Statistics, Statistical Division, Ministry of Planning, Government of the People's Republic of Bangladesh, Dhaka.

Brown J. E., Serdula, M., Cairns, K., Godes, J. R., Jakobs, Jr. D. R., Elmer, P. and Rowbridge, T. 1986. Ethnic growth differences in nutritional status of young children from low income areas of an urban country. Amer J Clinic Nutri 44(6), 938-944.

Chen L. C., Huq, E. and D'souza, S. 1981. Sex bias in the family allocation of food and health care in rural Bangladesh. Population Dev Rev 7, 55-70.

De Lira, P. I., Cartegena, H. A., Romani, S. D. E., Torres, M. A. and. Batista F. M. 1985. Nutritional status of children under 6 according to land tenure in rural areas of the state of Peramlunco, North east of Brazil. Arch-Latin oam-nutr 35(2), 247-257.

Fairbanks V. F. 1994. Iron in medicine and nutrition. In "Modern Nutrition in Health and Disease" [M. E. Shills, J. A. Olson and M. Shike, Eds. (Eight Edn.)], Lea and Febiger, New York. pp 185213.

Food and Agricultural Organization (FAO). 1970. "Lives in Preliminary Protein and the Child". No. 11, FAO, Rome.

Food and Agricultural Organization (FAO). 2002. "The State of Food Insecurity in the World". FAOUN, Rome.

GPRB. 1995. Ministry of Health and Family Welfare, and the Bangladesh National Nutrition Council: Bangladesh Country Paper on Nutrition. Government of the People's Republic of Bangladesh, Dhaka.

Jahan, K. and Hossain, M. 1998. Nature and Extent of Malnutrition in Bangladesh: Bangladesh National Nutrition Survey, 1995-96. Institute of Nutrition and Food Science, University of Dhaka, Bangladesh, Dhaka.

Jalal, F., Nesheim, M. C., Agus, Z., Sanjur, D. and Habicht, J. P. 1998. Serum retinol concentrations in children are affected by food sources of $\beta$-carotene, fat intake and anathematic drug treatment. Amer J Clinic Nutri 68, 623-629.

Kramer, E. M., Petersen, K. E., Rogers, B. L. and Hughes, M. D. 1997. Intra-household allocation of energy intake among children under five years and their parents in rural Bangladesh. Euro. J Clinic Nutri 51, 750-756.

Olson, J. A. 1994. Vitamin A, retinoids, and carotenoides. In "Modern Nutrition in Health and Disease" [M. E. Shills, J. A. Olson and M. Shike, Eds. (Eight Edn.)], Lea and Febiger, New York. pp. 287-307.

Puffer, R. R. and Serrano, C. V. 1973. "Patterns of Mortality in Children". PAHO, WHO.

Scrimshaw, N. S. and Gordon, J. E. 1968. Am J Public Heath 58, 505.

UNICEF. 1999. "Information Statistics". United Nations International Children's Emergency Fund.

Villavieja, G. M., Valerio, T. E., Abaya, H. S. P., Cerdena, C. M. and Domdom, A. C. 1984. Second nationwide nutrition survey: Philippines, Part A. Food Consumption Survey. FNRI-DOST. (Summary Report). 